\title{
Phylogenetic revision of Backhousieae (Myrtaceae): Neogene divergence, a revised circumscription of Backhousia and two new species
}

\author{
Mark G. Harrington ${ }^{\mathrm{A}, \mathrm{G}}$, Betsy R. Jackes ${ }^{\mathrm{B}}$, Matthew D. Barrett ${ }^{\mathrm{C}, \mathrm{D}, \mathrm{E}}$, Lyn A. Craven $^{\mathrm{F}}$ \\ and Russell L. Barrett ${ }^{\mathrm{C}, \mathrm{D}, \mathrm{E}}$ \\ ${ }^{A}$ Australian Tropical Herbarium, James Cook University, Cairns, Qld 4870, Australia. \\ ${ }^{B}$ School of Marine and Tropical Biology, James Cook University, Townsville, Qld 4811, Australia. \\ ${ }^{C}$ Botanic Gardens and Parks Authority, Kings Park and Botanic Garden, West Perth, WA 6005, Australia. \\ ${ }^{D}$ School of Plant Biology, Faculty of Natural and Agricultural Sciences, The University of Western Australia, \\ Crawley, WA 6009, Australia. \\ EWestern Australian Herbarium, Department of Environment and Conservation, Locked Bag 104, \\ Bentley Delivery Centre, WA 6983, Australia. \\ ${ }^{\mathrm{F}}$ Australian National Herbarium, Centre for Australian National Biodiversity Research, CSIRO Plant Industry, \\ Canberra, ACT 2601, Australia. \\ ${ }^{\mathrm{G}}$ Corresponding author. Email: Mark.Harrington@jcu.edu.au
}

\begin{abstract}
Backhousieae is a small tribe of Myrtaceae composed of two genera (Backhousia and Choricarpia) endemic to Australia. Phylogenetic analyses (parsimony, maximum likelihood and Bayesian) were performed on a combined chloroplast (matK, trn $\mathrm{H}-p s b \mathrm{~A}, \operatorname{trn} \mathrm{C}-p s b \mathrm{M}, \operatorname{trn} \mathrm{L}-\mathrm{F}, r p s 16)$ and nuclear (internal transcribed spacers) dataset for all nine species of Backhousia, two species of Choricarpia and two undescribed species. Backhousieae is monophyletic; however, Choricarpia is embedded within Backhousia. In all analyses there were four strongly supported clades containing two to four taxa, with no support for relationships among clades, and the relationships of B. bancroftii and B. citriodora remain unresolved. Bayesian relaxed-clock molecular dating indicated that the Backhousieae has been potentially present in rainforest across Australia for more than 50 million years. The current distribution of Backhousia is inferred to be largely due to the contraction of Australian rainforest in the Neogene. New combinations in Backhousia are made for the two species of Choricarpia, and B. gundarara and $B$. tetraptera are described as new species. B. gundarara is known only from the Kimberley region of Western Australia, widely disjunct from the remaining Backhousia in eastern Queensland and New South Wales, and appears to be a lineage isolated by increasing aridity during the Miocene.
\end{abstract}

Received 11 May 2012, accepted 29 October 2012, published online 14 December 2012

\section{Introduction}

Rainforests of tropical eastern Australia are renowned for their high levels of plant endemism, whereas the mostly small and fragmented patches of monsoon rainforest in northern Australia contain few local endemics and usually consist of easily dispersed and readily established species with wide distributions (Liddle et al. 1994). Within these northern rainforests, the regional endemic species might be indicative of an immigrant flora, with the subsequent speciation being associated with dispersal of Asian elements as the Australian plate collided with or came closer to the Sunda arc in the Early-Middle Miocene (Barlow and Hyland 1988). Alternatively, northern endemics could be remnants of a previously widespread rainforest flora that speciated in situ as the rainforests contracted because of increased drying and seasonality during this same period (Martin 2006). In the present study, we trace the evolutionary history of Australian tropical rainforest as reflected in an endemic tribe of the Myrtaceae.

The Backhousieae Peter G.Wilson (subfamily Myrtoideae) is one of the smallest tribes of Myrtaceae, consisting of two genera previously considered to be endemic to the eastern coastal region of Australia (Wilson 2011). Backhousia Hook. \& Harv. has 11 species (two undescribed) whereas there are only two species of Choricarpia Domin. The two species of Choricarpia were both originally described in the genus Syncarpia Ten. respectively by Mueller (1859) and White (1919). They are generally found as large or small trees in rainforest, monsoon forest and vine thickets. The tribe has been assessed for essential oils (Brophy et al. 1994, 1995), and is particularly known for the lemon-scented volatile leaf oil of Backhousia citriodora that is used in the generation of flavours and fragrances, as well as in aromatherapy. A family-wide study based on matK data and 
limited sampling within Backhousieae (two species of Backhousia and one species of Choricarpia) had a weakly supported (77\% jackknife) Choricarpia embedded in Backhousia (Wilson et al. 2005).

Many Backhousia species are recorded as hosts of or susceptible to the fungal plant pathogen Puccinia psidii sensu lato, a disease that affects trees and shrubs in the Myrtaceae, with Choricarpia leptopetala one of the four species recorded as severely damaged in native bushland (Carnegie and Lidbetter 2012).

In 2001, Backhousia sp. Prince Regent (W. O'Sullivan \& D. Dureau WODD 42) was first discovered in the Kimberley, Western Australia, $1800 \mathrm{~km}$ from the nearest other species in northern Queensland. There are only two known populations of this species in rainforest and vine thickets surrounded by steep cliffs. In 2010, a mysterious 'myrtaceous' single group of trees with distinctive winged fruits was identified in the Mount Stuart region near Townsville, northern Queensland, an area just south of the current extension of the Wet Tropics rainforest World Heritage Area. A DNA-based scientific investigation of a specimen of these trees by the first author placed them as also an undescribed taxon within Backhousieae.

The aims of the present study were to use molecular data from multiple chloroplast markers, combined with nuclear internal transcribed spacer data, to test the monophyly of the two genera of Backhousieae, and to determine the phylogenetic and biogeographic affinities of the two undescribed species within Backhousieae in a temporal framework, and to describe the new species.

\section{Materials and methods}

Sampling

All 11 currently described species of Backhousieae (nine from Backhousia and two from Choricarpia) plus two undescribed Backhousia species were sampled from living collections or herbarium specimens (Appendix 1). On the basis of the large Myrtaceae analyses of Biffin et al. (2010) and Thornhill et al. (2012a), outgroups were drawn from the sister tribe Syzygieae (six species), and the closely related Kanieae (two species), Metrosidereae (two species) and Tristanieae (two species). Sequences of these outgroups were downloaded from GenBank. Composite sequences for some outgroups were used where necessary for more complete sampling across all the markers (Appendix 1).

\section{DNA extraction, amplification and sequencing}

Genomic DNA was extracted using a DNeasy Plant Mini kit (Qiagen Inc., Valencia, CA, USA). We used primers from previously published studies, as follows: ITS - 17SE-26SE (Sun et al. 1994) or ITS4-ITS5 (White et al. 1990), for matK, trn $\mathrm{H}-p s b \mathrm{~A}, \operatorname{trn} \mathrm{C}-p s b \mathrm{M}, \operatorname{trn} \mathrm{L}-\mathrm{F}$ (Kress et al. 2005) and $r p s 16$ (Shaw and Small 2004). PCR amplifications in a total volume of $20 \mu \mathrm{L}$ contained reagents at a final concentration, as follows: $1.25 \times$ PCR buffer, $1.8 \mathrm{mM} \mathrm{MgCl}_{2}, 250 \mu \mathrm{M}$ dNTPs, $0.5 \mu \mathrm{M}$ each primer, $4 \%$ DMSO and $0.5 \mathrm{mg} \mathrm{mL}^{-1} \mathrm{BSA}$ and template DNA as required. Thermal cycling conditions involved 1 cycle of $2 \mathrm{~min}$ at $95^{\circ} \mathrm{C}$, followed by 35 cycles of $1 \mathrm{~min}$ at $95^{\circ} \mathrm{C}, 30 \mathrm{~s}$ at $50^{\circ} \mathrm{C}$ and 1 min at $72^{\circ} \mathrm{C}$, followed by 1 cycle of $2 \min$ at $72^{\circ} \mathrm{C}$. PCR products were purified using Fermentas exonuclease (20 units $\mu \mathrm{L}^{-1}$ ) (www.fermentas.com, accessed 8 November 2012) and shrimp alkaline phosphatase $\left(1 \mathrm{u} \mu \mathrm{L}^{-1}\right)$ where $10.0 \mu \mathrm{L}$ of PCR product was added to $4.0 \mu \mathrm{L}$ of purification agent ( $2 \%$ exonuclease and $20 \%$ shrimp alkaline phosphatase); samples then underwent a thermal program $\left(37^{\circ} \mathrm{C}\right.$ for $20 \mathrm{~min}, 80^{\circ} \mathrm{C}$ for $15 \mathrm{~min}$ ). Amplification primers were also used as sequencing primers. Cleaned PCR products were sequenced in both directions at the Australian Genome Research Facility, Brisbane. Chromatograms were edited with Chromas Pro v.1.4.1 (Technelysium Pty Ltd, Brisbane, Qld).

\section{Phylogenetic analyses}

Sequences were aligned by eye where there was little or no ambiguity, or by using the online version of MAFFT v.6, with the Q-INS-i algorithm for ITS and G-INS-i algorithm for trnH-psbA and default parameters (Katoh and Toh 2008). Initially, the nuclear ITS and combined chloroplast (matK, $\operatorname{trn} \mathrm{H}-p s b \mathrm{~A}, \operatorname{trn} \mathrm{C}-p s b \mathrm{M}, \operatorname{trn} \mathrm{L}-\mathrm{F}$ and $r p s 16)$ datasets were analysed separately in Mr.Bayes v. 3.1.2 (Ronquist and Huelsenbeck 2003). Combined $v$. separate partitioning schemes for the plastid sequences were assessed using Bayes factors (Brown and Lemmon 2007) in Tracer 1.5 (Rambaut and Drummond 2007), which resulted in lack of support for using the more complex model. Similarly, the best fitting model for each partition was also selected using Bayes factors comparisons (Kass and Rafferty 1995). Given that there was no evidence of conflicting phylogenetic signal in the separate analyses (branches receiving posterior probabilities of $\mathrm{PP} \geq 0.95$ ), all subsequent analyses were performed on a concatenated dataset.

For the combined dataset maximum parsimony (MP) jackknife analyses performed in PAUP*4.0b10 (Swofford 2002) consisted of 1000 replicates containing heuristic searches with 10 random taxon-addition sequences and treebisection and reconnection. Maximum likelihood (ML) phylogeny estimation and fast bootstrapping (1000 replicates with the GAMMA approximation, Stamatakis et al. 2005) was performed using RAxML v.7.2.7 on Teragrid from the CIPRES Science Gateway (Miller et al. 2010), using the partition by genes with a general time-reversal $(\mathrm{GTR})+\mathrm{I}+\Gamma$ model for each partition. Bayesian estimations of the PPs of phylogenetic trees performed in MrBayes v.3.2.1 (Ronquist and Huelsenbeck 2003) had uninformative priors on model parameters, with a GTR $+\mathrm{I}+\Gamma$ substitution model for each of the combined chloroplast and nuclear partition. Four independent runs of 1 million generations, consisting of two separate analyses, with two runs per analyses, sampling every 100 generations, were performed. Convergence of the independent runs to similar stationary distributions for the MCMC samples were assessed in Tracer 1.5 (Rambaut and Drummond 2007) by checking for overlapping joint marginal distributions of sampled parameters.

\section{Divergence time estimation}

Bayesian estimations of divergence times were implemented in BEAST v.1.6.2 (Drummond and Rambaut 2007), with a GTR $+\mathrm{I}+\Gamma$ unlinked substitution model for each of the two partitions, a Yule birth rate prior on branch rates that assumes a constant lineage birth rate for each branch in the tree, and 
uncorrelated log-normal distribution for the relaxed-clock model. Four independent runs of 10 million generations, sampling from the prior distribution every 250 generations, were performed. Values of logs of all parameters for all runs were compared in Tracer 1.5 (Rambaut and Drummond 2007) to verify convergence to the same posterior distribution post-burnin and to ensure sufficient effective sample sizes for all parameters (ESS > 200). There are no pollen or macrofossils that can be directly attributed to Backhousieae (Sniderman and Jordan 2011). The only node constraint we applied was a secondary calibration to the stem of Backhousieae, based on the large Myrtaceae combined macrofossil and pollen-calibrated analysis of Thornhill et al. (2012a) that obtained a 95\% highest posterior density (HPD) for that node of 35.2-58.17 million years ago and a median of 46.9 million years ago, and is virtually equivalent to ages produced for this node in the analyses of Biffin et al. (2010). The analysis of Thornhill et al. (2012a) also included a Myrtaceidites eugeniioides Cookson \& Pike fossil pollencalibrated divergence between Syzygieae and Backhousieae with an exponential prior distribution (mean 1.952, offset 48.6). We used a log-normal prior (mean 39.2, s.d. 0.17, offset 10.1, mean in RealSpace $=$ true) to incorporate the estimation error of the 95\% HPD for the estimated divergence of Backhousieae from Syzygieae from the anaylsis of Thornhill et al. (2012a).

The tempo of extant lineage accumulation within Backhousieae (speciation minus extinction) was visualised with a lineage through time (LTT) plot. The logarithm of the number of extant lineages against node heights (mean and 95\% HPD) were plotted from the maximum clade-credibility chronogram with all outgroups excluded. A constant birth-death speciation model will return a straight line (Barraclough and Vogler 2002), and deviation from a constant rate was tested for by using the $\gamma$-statistic, which describes the distribution of nodes within a phylogeny under the assumption that a clade diversifying under a constant rate follows a normal distribution, with a mean of zero and a standard deviation of one. The null hypothesis of a constant rate is rejected if $\gamma<-1.645$ (speciation-rate decrease towards present) and $\gamma>+1.645$ (speciation-rate increase towards present) (Pybus and Harvey 2000).

\section{Results}

The aligned concatenated dataset included 25 taxa and was 5428 nucleotides long, including gaps and missing data (nuclear 627 and chloroplast 4801 base pairs). The independent runs of the MrBayes analyses on the combined dataset converged on identical topologies. The maximum clade-credibility chronogram from one of the BEAST analyses is shown in Fig. 1, with PP from Mr Bayes, and ML and MP jackknife values shown on supported nodes. Syzygieae is supported as sister to Backhousieae (0.96 PP, 75\% ML bootstrap); however, in the MP analyses when Kanieae are used to root the analyses, Syzygieae forms a weakly supported clade with Metrosidereae and Tristanieae, which is probably the result of long-branch attraction caused by the restricted sampling among the outgroups. In all analyses, there were four strongly supported clades containing between two and four taxa, with no support for relationships among clades, whereas the relationships of B.bancroftii and B. citriodora remain unresolved. The only difference between the analyses within a monophyletic Backhousieae (1.0 PP, 100\% ML bootstrap, 100\% MP jackknife) is that Backhousia citriodora is weakly supported as sister to the clade containing $B$. $s p$. nov. from Mount Stuart, B. myrtifolia and B. enata in the MP jackknife $(52 \%)$ and MrBayes (0.52-0.57 PP) analyses. The two species of Choricarpia are sister to a clade that contains $B$. hughesii and $B$. sp. Prince Regent (1.0 PP, $75 \%$ ML bootstrap, $78 \%$ MP jackknife). Majority rule consensus topology with branch lengths proportional to the inferred number of changes along that branch from the first two MrBayes runs is shown in Fig. 2.

\section{Diversification of Backhousieae}

The Bayesian uncorrelated log-normal estimation of phylogeny and substitution rates indicated a moderate degree of rate heterogeneity among branches, with the $95 \%$ CI coefficient of variation significantly removed from zero (mean 0.36, HPD $0.22-0.50$ ), justifying the use of a relaxed molecular-clock analyses. There was no substitution-rate autocorrelation among related branches in the phylogeny because the $95 \%$ CI of the covariance statistic was not significantly removed from zero (mean zero, HPD -0.24-0.28). The effective sample sizes (number of independent samples from the marginal posterior or prior distributions) for all designated nodes of interest in all analyses were $>200$, indicating that the MCMC chains were run for adequate lengths.

Diversification (speciation minus extinction) within Backhousieae has not been constant, as indicated by the variation from the dotted straight line (LTT plot, insert, Fig. 1). There is an increase in net diversification between 10 and 28 million years ago, followed by an easing off from 0 to 10 million years ago. The gamma statistic $(\gamma=1.789)$ confirmed a slowdown in net diversification rate over recent time.

\section{Discussion}

The analyses of the combined nuclear and chloroplast dataset produced a well-supported phylogeny that supplies the basis for a hypothesis of relationships within a monophyletic Backhousieae that includes the two species of Choricarpia embedded within Backhousia and sister to B. hughesii and B. sp. Prince Regent. Further analyses in MrBayes constraining a reciprocally monophyletic Backhousia and Choricarpia produced a $\log 10$ Bayes factor comparison (3.127), which is strong evidence favouring the unconstrained hypothesis (Kass and Rafferty 1995). The potential of a close relationship between Choricarpia and Backhousia was first alluded to by Ingle and Dadswell (1953) on the basis of timber anatomy and, subsequently, by Bamber (1962) on the basis of bark features, whereas the synapomorphy for inclusion of both genera in Backhousieae is having cotyledons incumbent to the hypocotyl (Wilson et al. 2005). The two species of Choricarpia have a globose head of unfused sessile flowers (fused at the base in C. subargentea). Whereas the unit inflorescences are heads, conflorescences that are raceme-like do occur. These are borne terminally or axillary, and all seem to end in vegetative buds. Often the pedunculate heads occur in pairs in the axils, a 


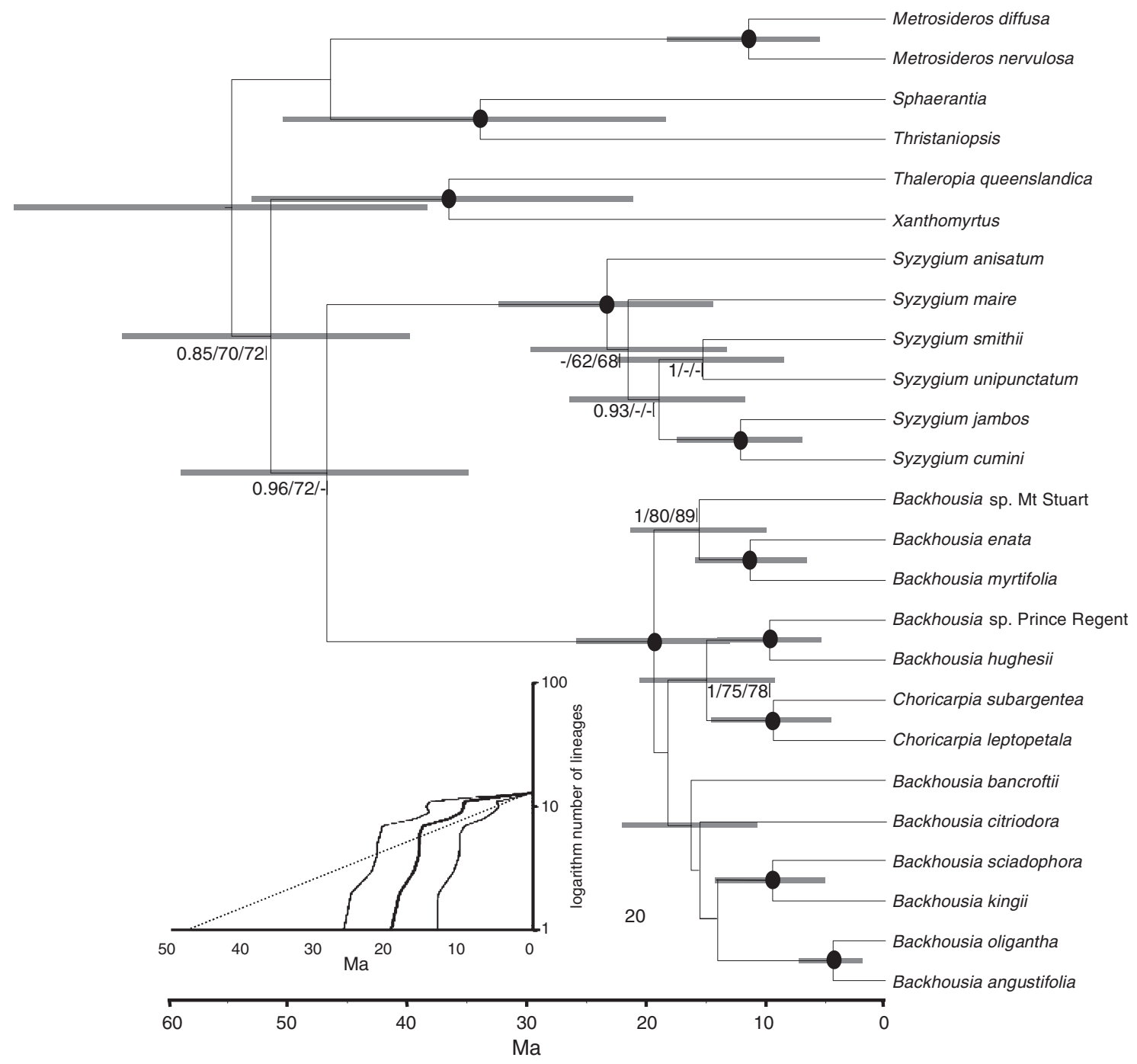

Fig. 1. Timing of the diversification of Backhousieae. Maximum clade-credibility tree estimated from the Bayesian analyses using BEAST and the concatenated dataset. Node positions indicate mean estimated divergence times and node bars are their $95 \%$ highest posterior density. Black circles represent posterior probabilities of 1.00 from MrBayes analyses, maximum likelihood bootstrap and parsimony jackknife $>90 \%$. Other values, in the same order, $>50 \%$ are shown below nodes supported. Graphical insert shows lineage through time plot and $95 \%$ confidence interval derived from nodal divergence times obtained from the relaxed-clock estimations from BEAST analyses (solid lines), whereas the dotted line represents a constant diversification rate through time.

phenomenon that Briggs and Johnson (1979) called accessory branching. Most species of Backhousia have cymes or panicles, with only $B$. angustifolia having sessile flowers in heads of usually three flowers. There is a prominent stamen-bearing structure in all species of Backhousia, but this structure is not obvious in the two species of Choricarpia. The locules of twolocular ovary of Choricarpia each contain a solitary ovule with basal placentation. This condition sometimes occurs in the undescribed Backhousia from Mount Stuart that may have one or two ovules per locule, whereas $B$. sp. Prince Regent has subbasal placentation. All other Backhousia species have a few ovules generally arranged in a U-shape on a axile placenta. All species of Backhousieae have dry, indehiscent fruits. Generally, species of Backhousia have syncolporate pollen (sometimes weakly parasyncolporate), whereas the grains of Choricarpia are parasyncolporate, with a large apocolpial field (Gadek and Martin 1981). However, Thornhill et al. (2012b) reported pollen of both Backhousia and Choricarpa as parasyncolpate, suggesting variation in the size and prominence of the apocolpal field within Backhousia sens.lat.

Within Backhousieae, the four strongly supported clades generally reflect relationships previously suggested from morphology - B. enata sister to B. myrtifolia (Ford et al. 2005), and B. kingii sister to B. sciadophora (Guymer 1988).

\section{Evolutionary history and diversification of Backhousieae}

In the absence of any reliable fossil dates for Backhousieae, reliance on ages extrapolated from a secondary calibration point for inference of divergence dates means that a cautious approach 


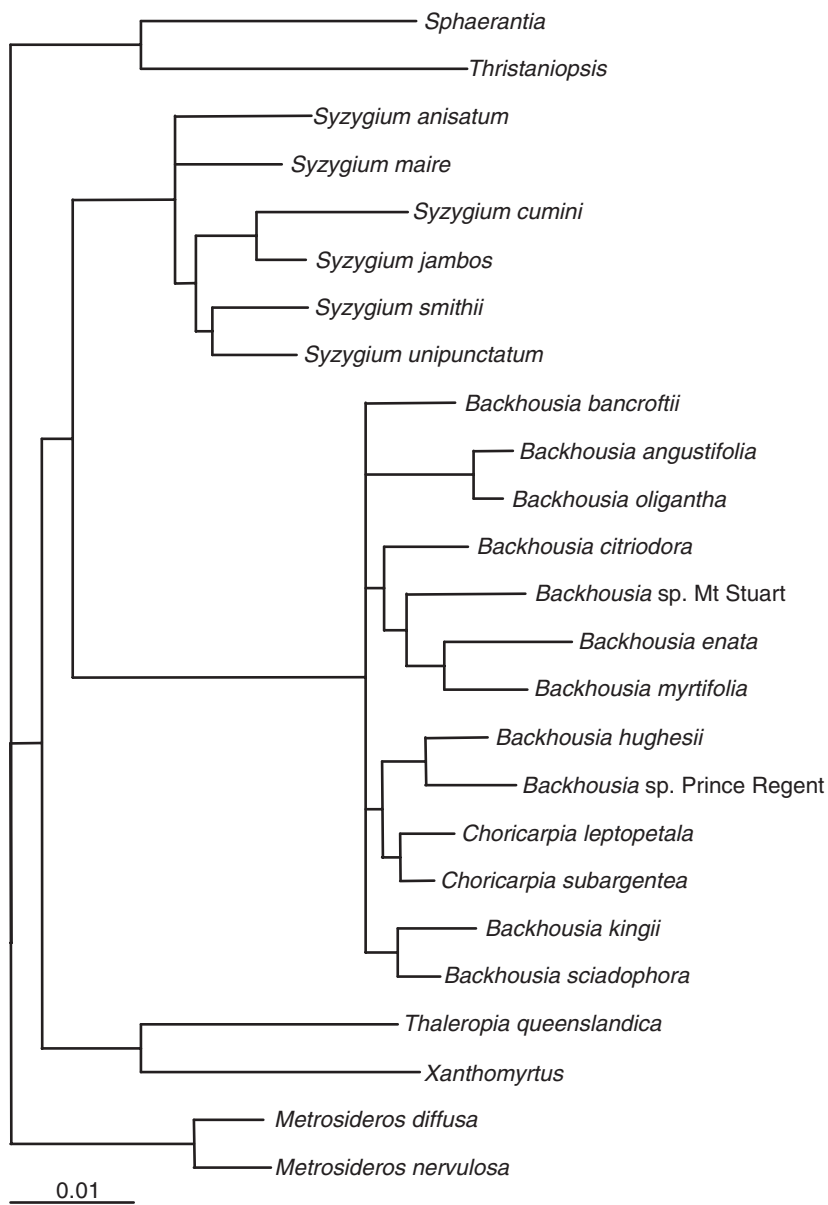

Fig. 2. Post-stationarity majority-rule consensus tree from the first MrBayes analysis (two runs) of the combined dataset, with branch lengths proportional to the inferred number of changes along that branch.

must be taken to interpreting divergence-time estimations across Backhousieae.

All the tribes of Mytoideae have a fairly old evolutionary history (see fig. 4 of Biffin et al. 2010 - stem ages), with the origin of Backhousieae (split from Syzygieae, stem Backhousieae) being dated to 35-59 million years ago $(95 \%$ HPD). The temporal accumulation of extant lineages within Backhousieae, as reflected in the shape of LTT curve, indicates a striking difference between initial period of 22-33 million years ago (95\% HPD) for the long stem branch of Backhousieae, followed by a period from 5 to 20 million years ago (95\% HPD) in the Neogene when most of the extant lineages diverged from their sister lineages. The slow-down in the accumulation of extant species from the Pliocene, and there being no evidence of Pleistocene speciation events in this chronogram $(95 \%$ HPD $<1.8$ million years ago), might be the result of extinction of lineages as a result of the dramatic climatic cycling of this epoch, or as a result of cryptic speciation that has not been identified by the current sampling protocol. The pattern of rapid extant lineage radiation in the Oligocene-Miocene in the Australian flora, preceded by a relatively long period of either evolutionary stasis or considerable extinction, i.e long stem branches, is also found in other tribes of Myrtaceae, namely, Eucalypteae and Syzygieae (Biffin et al. 2010).

Although there is some macro-fossil and pollen evidence that some parts of the Australian continent were covered with rainforest for much of the Late Cretaceous and Tertiary (see Martin 2006, for sites and interpretation), there are many gaps and uncertainties in the fossil record, especially concerning whether there was continuous rainforest across the Australian monsoon tropics. Paleoclimate modelling and paleoecological studies of vertebrate faunas have been equivocal in interpretation of these proxy records for the existence of rainforest in northern Australia in the Early to Middle Miocene (Travouillon et al. 2009, 2012; Herold et al. 2011; Greenwood et al. 2012).

The indehiscent dry fruits of Backhousieae have small seeds ( $1-2 \mathrm{~mm}$ long) and, although relying on abiotic dispersal mechanisms, do not appear to have any specific adaptations for wind-or water-dispersal and, generally, fresh seed is required for successful germination (Floyd 1989). The presence of two isolated populations of $B$. sp. Prince Regent from Western Australia that are sister to a rainforest-restricted $B$. hughesii from the Wet Tropics of far-northern Queensland is consistent with the proposition for the continued distribution of rainforest across the top of Australia in the Eocene. The now disjunct distribution is possibly the result of severe fragmentation of rainforest in the Neogene as a result of drying of the continent, in particular the development of savanna grasslands in northwestern Australia in the Late Miocene (Kershaw et al. 1994; Martin 2006), with the geographic isolation promoting speciation. Backhousia sp. Prince Regent is the only endemic species to be identified from the Kimberley rainforest fragments to have a sister lineage in eastern Australia rainforests. Myrsine kimberleyensis Jackes and Hibiscus peralbus Fryx. are the only other Kimberley-endemic rainforest species so far reported (Kenneally et al. 1991; Jackes 2005). Both species require further molecular work to explore their origins; however, at least $M$. kimberleyensis has an apparently close sister species in the Northern Territory and further relatives in eastern Australia (Jackes 2005). The remainder of the Kimberley rainforest flora is composed of species widespread in tropical Australia (Kenneally et al. 1991). Backhousia sp. Prince Regent occurs in the highest-rainfall zone of the Kimberley $\left(\sim 1400 \mathrm{~mm} \mathrm{year}^{-1}\right)$ and at the base of large escarpments that are likely to have provided a stable environment from water seepage. These factors may have assisted the persistence of this species in the Kimberley, despite increasing aridity during the Neogene.

There is very little evidence from other dated molecular phylogenies that is congruent with the temporal disjunction described above. There is a comparatively congruent disjunction between the northern Australian rainforest species in the Eucalypteae, with the Arnhem Land monotypic endemic Allosyncarpia ternate S.T.Blake being diverged from monotypic Wet Tropics endemic Stockwellia quadrifida D.J.Carr, S.G.M. Carr \& B.Hyland, and two species of Eucalyptopis; however, this is dated to the Oligocene (30-25 million years ago, Ladiges et al. 2003; 37-35 million years ago, Crisp et al. 2004). Other species disjunctions between Northern Territory rainforest taxa and species from rainforest in the Wet Tropics or McIlwraith Ranges in far-northern Queensland are generally more recent 
and are usually within fleshy-fruited clades, such as e.g. Annonaceae - Uvaria 2-0 million years ago (Zhou et al. 2012); Arecaceae - Carpentaria acuminata (H.L.Wendl. \& Drude) Becc/Wodyetia bifurcata A.K.Irvine 4 million years ago (Savolainen et al. 2006). Further molecular-dating studies are needed to determine whether patterns and timing of disjunctions are congruent across multiple taxa with similar dispersal syndromes.

The major diversification of extant Backhousieae, as identified in the LTT plot, took place within the Neogene (14-24 million years ago), with a slowdown in diversification from then to the Present. There is a sister species relationship consistent with the possibility of rainforest contraction on the eastern coast of Australia within a similar time period to the northern disjunction. The Wet Tropics narrow endemic $B$. enata split from $B$. myrtifolia 7-16 million years ago and are now geographically separated by over $1000 \mathrm{~km}$, with B. myrtifolia current distribution extending from Fraser Island in Queensland to the temperate rainforests at Bega in southern New South Wales. The sister to these two species is an undescribed Backhousia that is now found only in a fire-protected gully on Mount Stuart, Townsville, just outside the southern extent of the current Wet Tropics rainforests.

The low diversification rate in Backhousieae (13 species) compared with that in its sister clade, the predominantly Australasian rainforest Syzygieae (1189 species), has been shown to be correlated with differences in dispersal ability (dry fruit, abiotic dispersal $v$. fleshy fruit, biotic dispersal), with the latter being a key innovation for rainforest Myrtaceae (Biffin et al. 2010).

\section{Taxonomic treatment}

Morphological and molecular comparison with other Backhousia species confirms that the two new species are typical members of Backhousia, being clearly differentiated from other species by a combination of morphological features, and both are described as a new species below. New combinations in Backhousia are also made for the two species of Choricarpia.

\section{Backhousia gundarara M.D.Barrett, Craven \& R.L.Barrett, sp. nov.}

Shrub or small tree up to $7 \mathrm{~m}$, bark smooth to base. Mature branchlets terete. Leaves opposite, petiolate, 17-35 × 11-24 mm. Inflorescence thryrsoid, of opposite dichasial cymes in leaf-like bract axils, each dichasial cyme with (1)2-9 flower clusters, each flower cluster with 4-15 flowers per cluster. Hypanthium stipe 0.5-1.5 mm long, 0.4-0.6 $\mathrm{mm}$ in diameter. Flowers four-merous. Calyx lobes scarcely dimorphic.

Type: Western Australia: Northern Botanical Province: Caroline Range, M.D. Barrett \& R.L. Barrett MDB 2885, 27 March 2010. Holotype: PERTH 08309574; isotypes: BRI, CANB.

Backhousia sp. Prince Regent (W. O'Sullivan \& D. Dureau WODD 42) (Western Australian Herbarium, in FloraBase, available at http://florabase.dec.wa.gov.au, accessed 14 February 2011).

Single- to multi-stemmed shrub or small tree up to $7 \mathrm{~m}$ high, often with coppice shoots and smaller juvenile plants with suckering and self-layering shoots; trunk diameter up to $\sim 20 \mathrm{~cm}$, buttresses absent; bark completely deciduous to base, smooth, peeling and somewhat mottled dark reddish-brown over orange-cream; ultimate branchlets almost smooth with very thin, appressed or lifting flaky grey to greyish-brown bark; indumentum uniformly puberulent on most parts (branchlets, petioles, lower leaf blade, inflorescence axes, stipes, hypanthia, calyx lobes and petals), of ascending, uniseriate, whitish hairs $\sim 0.1-0.4 \mathrm{~mm}$ long; branchlets flattened to slightly 4-ribbed when young, \pm terete when older, puberulent with hairs up to $0.4 \mathrm{~mm}$ long, but mostly $0.1-0.2 \mathrm{~mm}$ long, dotted with sessile emergent and embedded glands. Stipules caducous, subulate, $\sim 0.3-0.4 \mathrm{~mm}$ long. Cataphylls not seen. Leaves simple, opposite-decussate; petioles 2.0-4.5 mm long, 0.4-1.0 mm wide, channelled on upper surface, glandular, densely clothed in white ascending hairs when young, becoming sparsely hairy in age. Lamina ovate to elliptic or sometimes broadly ovate, $17-35 \times 11-24 \mathrm{~mm}$, slightly to distinctly discolorous, both surfaces hairy; abaxial surface when young with moderately dense, ascending white hairs on side, becoming dense and ascending on midvein, in age becoming sparsely hairy; adaxial surface initially sparsely ascending-hairy becoming dense on midvein, becoming glabrescent or glabrous, sometimes subglossy, with dense, prominent oil glands on both surfaces, base broadly cuneate to rounded, apex obtuse to broadly acute, not or very weakly and abruptly acuminate, margin flat or slightly recurved, entire to crenate; midvein plane or slightly sunken above, raised below; secondary venation conspicuous, with (5-)10-12 lateral veins each side of midvein at $\sim 50-60^{\circ}$, only slightly more prominent below than above; tertiary venation inconspicuous, reticulate; intramarginal vein complete, $0.5-2.0 \mathrm{~mm}$ from the margin, indented to slightly looping at junction with lateral veins. Inflorescences terminal/ subterminal and not or shortly exceeding leaves at anthesis (but becoming distinctly axillary after fruiting as terminal shoot grows out), thryrsoid, composed of a dichasial cyme in each axil of distal 1-3 leaf-like bracts, dichasia up to $75 \times 30 \mathrm{~mm}$, each dichasium with 1 or 2 orders of branching and terminated by (1-)2-9 flower clusters (never single flowers), all flowers in a cluster arising from a slightly expanded node, 4-15 flowers per cluster but many soon aborting, 6-25 (or probably more) flowers maturing in an inflorescence; primary inflorescence axis 6-42 $\mathrm{mm}$ long (rarely once-branched close to base), somewhat compressed in lower part, shallowly and irregularly angled and grooved above (not terete), moderately densely hairy with white hairs $0.1-0.25 \mathrm{~mm}$ long; lateral branches (0-)1-2, 1.0-9.5 mm long, 0.5-0.8-mm diameter, indumentum and section as primary branches; bracteoles linear-spathulate, $0.7-1.5 \mathrm{~mm}$ long, brown, densely hairy with white hairs $\sim 0.1-0.15 \mathrm{~mm}$ long, apex very narrowly cucullate-obtuse, but soon drying, brown and dry at anthesis, caducous. Flowers white, epigynous, 4-merous; hypanthium stipe $0.5-1.5 \mathrm{~mm}$ long, $0.4-0.6-\mathrm{mm}$ diameter, not filiform, gradually tapering into hypanthium proper, with indumentum as hypanthium; hypanthium stipitate, urceolate, $4.0-6.0 \mathrm{~mm}$ long, $2.4-2.7 \mathrm{~mm}$ wide, terete in section, not ribbed, clothed in fine moderately dense pale unicellular hairs over outer surface, the hairs white, mostly $\sim 0.2 \mathrm{~mm}$ long, but sparse hairs $\sim 0.4 \mathrm{~mm}$ long, emergent from main indumentum; calyx lobes 4, subequal, the outer pair slightly larger than inner pair, oblong to obovate, outer pair $1.5-1.9 \mathrm{~mm}$ long, $1.4-1.7 \mathrm{~mm}$ wide, inner pair $1.4-1.5 \times \sim 1.2-1.4 \mathrm{~mm}$, flat to slightly cucullate, apices 
obtuse, emarginate or subtruncate, abaxial surface densely hairy as hypanthium, adaxial surface glabrous or sparsely hairy in basal 1/2-2/3, moderately densely hairy with white appressedascending hairs $\sim 0.3 \mathrm{~mm}$ long in upper $1 / 3-1 / 2$, persistent in fruit, not obviously accrescent in fruit; oil glands sparse, conspicuous; petals 4, suborbicular to ovate, $1.5-2.0 \mathrm{~mm}$ long, $1.4-1.7 \mathrm{~mm}$ wide, with a short claw $0.2-0.3 \mathrm{~mm}$ long, flat to slightly cucullate, conspicuously hairy on both surfaces, especially in central-lower $2 / 3$ of abaxial surface where long white ascending hairs 0.5- $-0.7 \mathrm{~mm}$ long, shorter and sparser elsewhere, few to several scattered oil glands present especially near base, margin entire, becoming erose as aging, caducous after anthesis. Stamens 57-59 in 2 whorls (only 3 counted from a single inflorescence), filaments free, \pm dimorphic, inner series $2.0-3.5 \mathrm{~mm}$ long, outer series $4.0-5.5 \mathrm{~mm}$ long, $\sim 0.1-\mathrm{mm}$ diameter, glabrous, anthers \pm medifixed, versatile, $\sim 0.4 \times 0.35-0.4 \mathrm{~mm}, 2$-celled, dehiscing laterally by slits as long as the anther cells, apical gland prominent, free, subglobose, slightly protruding above level of anthers, connective not swollen, pollen $\sim 13 \mu \mathrm{m}$, weakly parasyncolpate, oblate, triangular in polar view, verruculose (Fig. 3). Style central, filiform, straight, $\sim 5.5 \mathrm{~mm}$ long, $\sim 0.5-\mathrm{mm}$ diameter at base, gradually tapering to apex, hairy, the hairs white to colourless, up to $4.0 \mathrm{~mm}$ long, moderately dense in basal $\sim 1 / 3$, becoming sparse over central third, apical third of style with only a few scattered hairs, stigma not expanded, minutely papillose; ovarian region $2.0 \times 1.75 \mathrm{~mm}$ (ovary cavity $\sim 0.8 \mathrm{~mm}$ wide), obovate, adnate to hypanthium for whole length, 2-locular, ovules 5-7 per locule, placentation sub-basal. Nectaries absent. Fruit dry, indehiscent, enclosed in the hypanthium, 6-7 $\times 4.5-5.0$ including persistent calyx lobes, 4-5 $\times 2-3$ excluding calyx lobes, calyx lobes \pm ascending, style persistent. Seeds (immature) comma-shaped; testa not seen (Figs 3, 4).

\section{Additional specimens examined}

Western Australia. Northern Botanical Province: Prince Regent River Reserve, Gundarara Creek, W. O'Sullivan \& D. Dureau WODD 42, 18

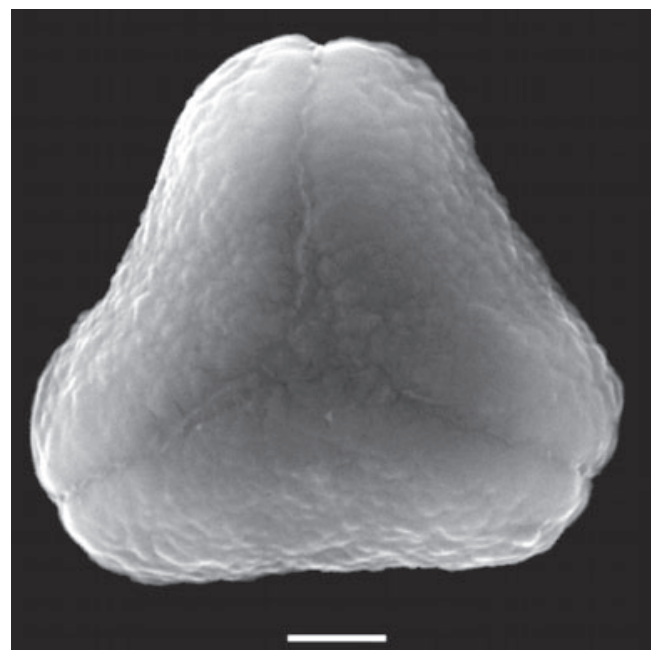

Fig. 3. Scanning electron microgram of pollen of Backhousia gundarara, sp. nov., from type specimen. Scale bar $=2 \mu \mathrm{m}$.
August 2001 (PERTH, CANB); Caroline Range, G. \& N. Sankowsky Sanko 2255, 16 September 2003 (PERTH).

\section{Distribution and habitat}

Known only from two locations near the upper reaches of the Prince Regent River, in each case associated with cliffs. The type population occurs in rainforest at the base of a sandstone cliff, at the junction with a basalt layer. The entire rainforest patch of the type location was searched in 2007 and 2008; taking clonality into account, we estimate fewer than 20 plants at this site; others have reported finding up to 50 suckers (probably mostly clones) at the same site. The second population occurs in sand over sandstone along ledges elevated above the floor of a gorge (W. O'Sullivan, pers. comm.), and reported to be 'frequent but restricted'. At the type locality, plants are completely fire protected, occurring well away from the margins of the rainforest patch that is sometimes fire-damaged. Plants at the second site would also be substantially fire-protected.

\section{Phenology}

Appears to flower for a short period during March-April. The only collection in anthesis was made in late March; fruits have been collected in early May (very old fruit in August); no inflorescences or buds were observed in late January.

\section{Etymology}

The species epithet comes from an Aboriginal name associated with the area where one of the populations was found.

\section{Conservation status}

Apparently highly restricted in distribution, and known only from small, fire-protected pockets. Currently listed as 'P2 Poorly known taxa' under the Western Australian Department of Environment and Conservation (DEC) system of conservation codes for Western Australia. Further surveys are required to assess distribution, threats and monitor stability, because the upper Prince Regent River area contains many unsurveyed deep gorges and rainforest pockets that could harbour B. gundarara.

\section{Notes}

Backhousia gundarara was first collected in August 2001 when two amateur botanists (D. Dureau and W. O'Sullivan) hiking through the upper Prince Regent River area of the Kimberley region discovered an unusual Myrtaceous tree resembling a guava, with smooth bark and opposite leaves. None of the plants was flowering; however, a lengthy search found a few old flowers (W. O'Sullivan, pers. comm.). This collection was divided between PERTH and CANB, but remained unplaced, in part because of the poor condition of the flowering material.

In September 2003, G. and N. Sankowsky discovered a small shrub in rainforest, also near the upper Prince Regent River. Although sterile, it was immediately recognised as a species of Backhousia. This specimen was again sent to PERTH and CANB. Lyn Craven agreed with the identification and asked M. and R. Barrett to collect fertile material during the wet season, the typical flowering season for a tropical Backhousia. 


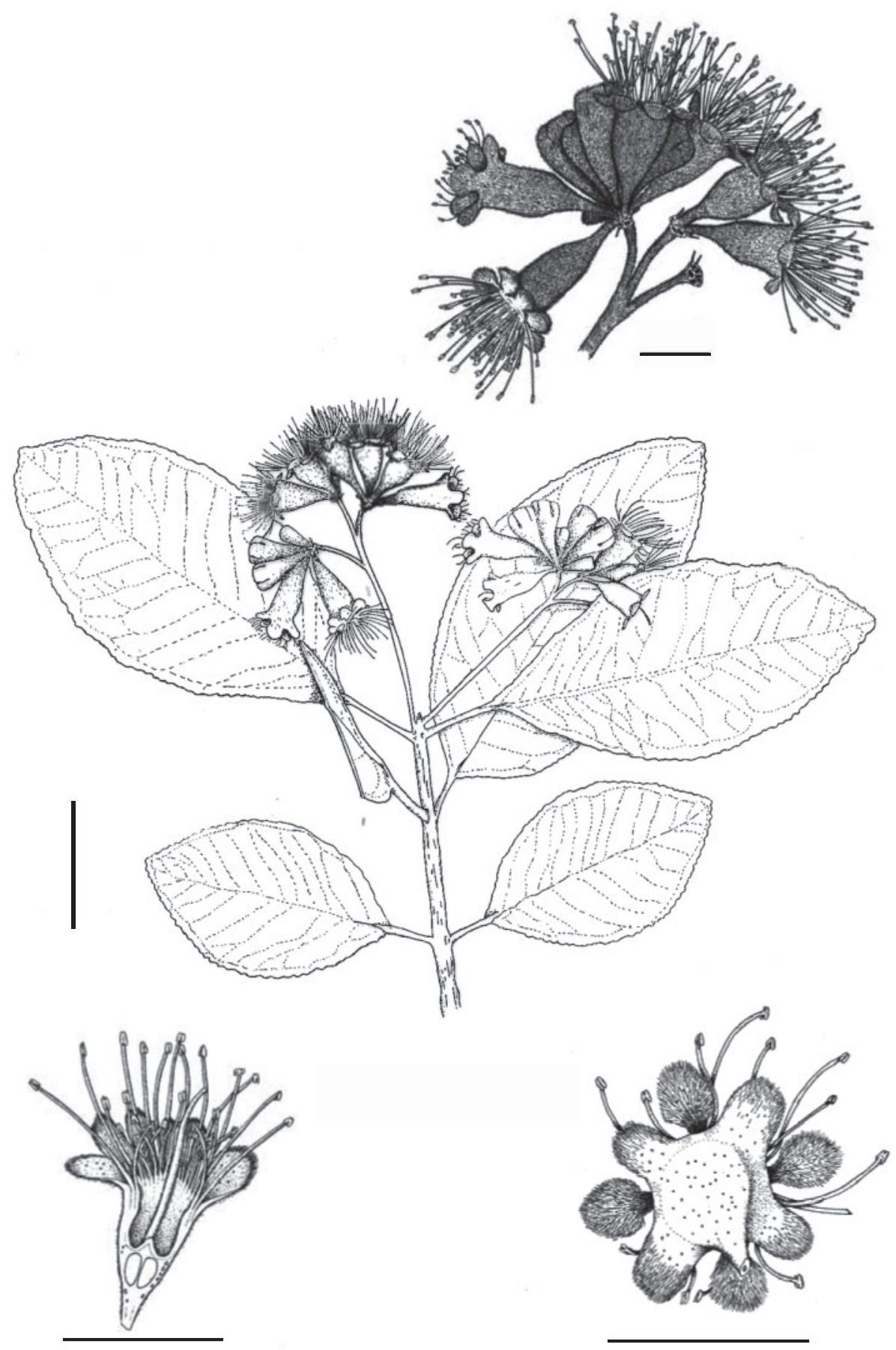

Fig. 4. Backhousia gundarara, sp. nov., from type specimen. Scale bars $=1 \mathrm{~cm}$ (centre), $5 \mathrm{~mm}$ (remainder). Del. Nadine Guthrie (PERTH).

The Sankowsky location was revisited by M. Barrett and R. Barrett in January 2007, when plants were sterile, again in late April 2008, when fruits were present, and finally in March 2010, when a single branch bearing fresh flowers was finally located.

In the key to Backhousia species presented in Ford et al. (2005), B. gundarara would key with B. oligantha A.R.Bean at
Step 6. It differs from $B$. oligantha in having more flowers per inflorescence (6-25 in B. gundarara v. 1-3 in B. oligantha), longer peduncles (6-46 mm long $v .1-3 \mathrm{~mm}$ in $B$. oligantha), \pm equal calyx lobes $v$. decidedly unequal in $B$. oligantha, shorter hypanthium stipes $(0.5-1.5 \mathrm{~mm}$ long in B. gundarara, $v$. 4-8 $\mathrm{mm}$ long in $B$. oligantha) and broader leaves $(11-14 \mathrm{~mm}$ wide $v$. 4.5-7 $\mathrm{mm}$ wide in B. oligantha). 
The inflorescences in the WODD specimen are in very old fruit, whereas inflorescences are distinctly axillary, more branched and considerably longer than in the type population. However, too little fertile material is available from either population to assess the significance of this variation.

\section{Backhousia tetraptera Jackes, sp. nov.}

Backhousia tetraptera is distinguished from other species by the four-angled perigynium associated with the flower and fruit. In mature fruits the inflated perigynium has four prominent wings.

Type: Queensland. North Kennedy District: Mount Stuart, Townsville, J.W.Elliott JE13 \& K. Townsend, 6 February 2012. Holotype: CNS 136890; isotypes: BRI, CANB, K, MO, NSW.

Tree up to $15 \mathrm{~m}$ tall, but usually $5-8 \mathrm{~m}$ tall, single- to multistemmed, coppicing; bark flaky, thin, grey, becoming mottled grey-brown to pink; lenticels on twigs inconspicuous, uniseriate hairs on new growth, $0.1 \mathrm{~mm}$ long; subrhytidome layer green, blaze pale brown with pale stripes. New growth red-purple; growth of new shoots proleptic. Stipules narrowly triangular up to $0.2 \mathrm{~mm}$ long, soon caducous. Leaves simple, opposite; petiole 6-8 $\mathrm{mm}$ long, channelled on adaxial surface, green to dark pink, if coloured, then this usually extends for some distance along the midrib, sparsely pubescent. Lamina lanceolate to elliptical, 5.5-9 cm long, 1.5-3.8 cm wide, weakly discolorous, glabrous, apex acute to acuminate, base cuneate, margins entire, often undulating; midrib on adaxial surface usually flat, on abaxial surface slightly raised, 10-12 lateral veins each side of midrib, angle of $30-45^{\circ}$; intramarginal vein $1 \mathrm{~mm}$ from margin. Oil glands visible on both surfaces of fresh leaves as bumps; stomata present only on abaxial surface. Juvenile leaves with petiole $1 \mathrm{~mm}$ long, lamina ovate to orbicular, up to $3 \mathrm{~cm}$ long, red-purple, when dry oil glands appear as pustules on adaxial and abaxial surfaces. Inflorescences terminal or axillary in upper axils, dichasial with 2-4 branches; 10 -flowered. Peduncle filiform $\sim 6 \mathrm{~mm}$ long, papillose; bracteoles minute, caduceus; pedicels filiform, $1 \mathrm{~mm}$ long, papillose. Flowers with perigynium 4-angled, $2 \times 1+\mathrm{mm}$ pubescent on both surfaces; calyx-lobes 4 , with 2 unequal pairs, outer pair $1.5 \times 1.5 \mathrm{~mm}$, inner pair $\sim 1 \times 1 \mathrm{~mm}$, both surfaces shortly pubescent, glands visible; petals 4 , white, $2 \mathrm{~mm}$ long including claw, $\sim 1.5 \mathrm{~mm}$ wide, papillose to pubescent on both surfaces, glands occasionally present. Stamens 56-65 in 2 whorls, filaments free, length varies within the one flower from 3 to $6 \mathrm{~mm}$ long, anthers dorsifixed, versatile, $0.25 \mathrm{~mm}$ long, terminal gland present, dehiscing through 2 longitudinal slits; pollen small, $\sim 20 \mu \mathrm{m}$, parasyncolpate, oblate, triangular in polar view. Style inserted in a shallow pit on summit of ovary, filiform, 5-6 mm long, scattered hairs near junction with ovary, oil glands sparse, stylar canal open, stigma punctiform; ovary $2 \mathrm{~mm}$ long, $\sim 1.5 \mathrm{~mm}$ wide, summit truncate, pubescent, oil glands sparse, 2-locular, 1 or 2 ovules per locule, placentation basal. Nectaries 4, club-shaped, $1 \mathrm{~mm}$ long, attached at the base of the ovary and hidden in a pocket in the perigynium corresponding to the angles. Fruit dry, indehiscent, enclosed by the inflated perigynium, white with pink blush drying brown; wings on perigynium prominent at maturity. Disseminule $6 \times 5 \mathrm{~mm}$. Seeds up to $0.8 \mathrm{~mm}$ long, rarely observed, embryo curved with more or less conduplicate cotyledons; many did not complete development or were parasitised (Fig. 5).

\section{Leaf anatomy}

Lamina dorsiventral, $0.2 \mathrm{~mm}$ thick, palisade mesophyll two rows thick, occupying $40 \%$ of transverse section; a third row occasionally present, the remainder consisting of spongy mesophyll cells. Midrib vascular bundle bicollateral, vascular tissue surrounded by fibres. Stomata present on abaxial surface only, paracytic, on average 17 per $0.04 \mathrm{~mm}^{2}$, with some giant stomata present. Oil-gland density similar on both sides, $11-12 \mathrm{~mm}^{-2}$; glands are capped by modified stomatal apparatus. Occasional calcium oxalate druse present near veins.

\section{Wood anatomy}

The wood anatomy is generally consistent with the description for Backhousia spp. by Wilson et al. (2000) and Ingle and Dadswell (1953). Bark thin, 1.5-2 mm thick, measured on a wood block of 10.5-11.5-cm diameter. Heartwood colour variable, chiefly pale brown in colour, sapwood paler, wood density varies from $790 \mathrm{~kg} \mathrm{~m}^{-2}$ to $910 \mathrm{~kg} \mathrm{~m}^{-2}$ (J. Elliott, pers. comm.) The denser sample was from a branch that had been on the ground for years (Blocks at CNS). Growth rings are reasonably easy to discern except near the centre; a transverse section of a branch of $10.5-11.5$-cm diameter had 180-212 rings. Wood weakly ring porous, fibres clustered to the outside of each ring, thick-walled with small oblique pits, 500-740 $\mu$ m long. Vessels are chiefly solitary or in radial multiples of 2-3; size and distribution varies from 280 to $450 \mu \mathrm{m}$ long, diameter $30-40 \mu \mathrm{m}$; perforation plate simple, pits rounded; no tyloses observed. Parenchyma mostly apotracheal, pits small, bordered similar to vessel pitting. Tracheids present incompletely vasicentric, length varies from 300 to $520 \mu \mathrm{m}$, diameter $\sim 20 \mu \mathrm{m}$. Rays uniseriate, weakly heterogeneous, marginal cells may be elongated.

\section{Oil}

In Brophy et al. (1995), the oils of nine species of Backhousia are described. Subsequently, Brophy et al. (2007) investigated the oils of $B$. enata A.J.Ford, Craven \& J.Holmes. An initial analysis of the leaf oils of $B$. tetraptera by nuclear magnetic resonance spectroscopy indicated that the predominant oil was myrtenyl acetate (B. Bowden, pers. comm.). A gas chromatographic analysis by J. Brophy confirmed this result (J. Brophy, unpubl. data 2011); he also found traces of several other unusual compounds. Myrtenyl was detected in both $B$. oligandra (described as B. sp. Didcot P.I.Forster PIF12617) (Brophy et al. 1995) and B. enata (Brophy et al. 2007).

\section{Additional material examined}

Queensland. North Kennedy: Mount Stuart, Townsville, J.W. Elliott JE3, 5 July 2010; J.W. Elliott JE10 \& K. Townsend, 21 October 2010 (CNS, JCT); J.W. Elliott JE12 \& K. Townsend, 16 January 2012 (CNS, BRI, CANB, NSW, K, MO); J.W. Elliott JE14 \& K. Townsend, 6 February 2012 (JCT).

\section{Distribution and habitat}

Backhousia tetraptera is known from only one population located in a gully on Mount Stuart $\left(19^{\circ} 20^{\prime} \mathrm{S}, 146^{\circ} 47^{\prime} \mathrm{E}\right)$, at an altitude of 


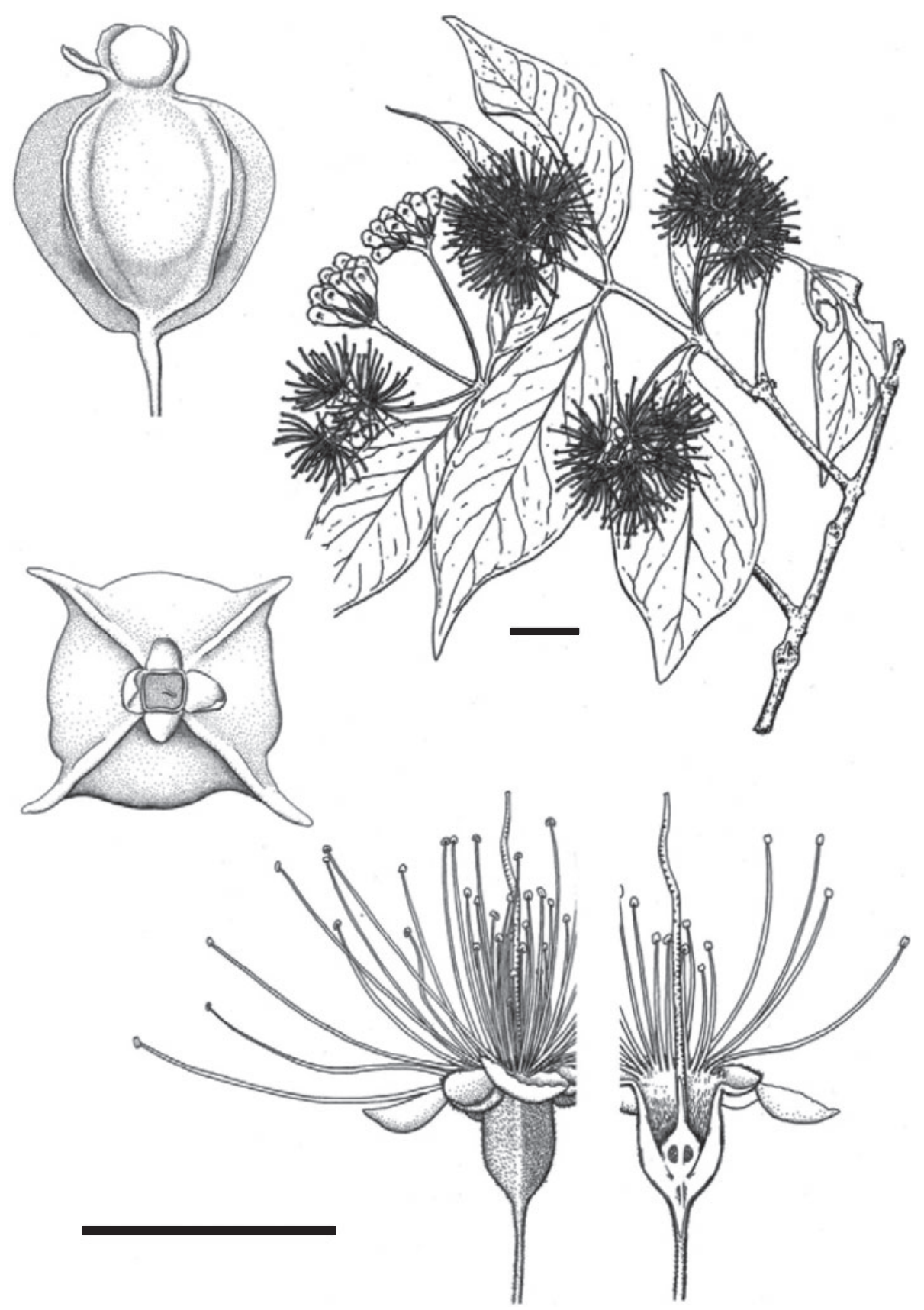

Fig. 5. Backhousia tetraptera, $s p$. nov., flowers from J.Elliott 11 (CNS), fruit from type specimen. Scale bars $=5 \mathrm{~mm}$ (both). Del. Ashley Field (CNS).

$500 \mathrm{~m}$. In this population $\sim 170-180$ individual trees were recorded. This grove occurs in a deep gully protected by ridges to the east and west. The granitic substrate is moist most of the year, particularly if in the shade; during the dry period of the year it is fed by seepage. Trees extend along this gully for $\sim 350 \mathrm{~m}$. The area is frequently covered in cloud at night, particularly in the summer months. No specimens were growing more than $2 \mathrm{~m}$ above the bottom of the gully, juveniles were scattered throughout (observations by J. W. Elliott, K. Townsend and P. Thomas - Society for Growing Australian Plants). Although there is evidence of the population having been affected by fire in the past, most plants appear to be protected by the rocky substrate and topography. Although juveniles are present, expansion of the population is unlikely because of an apparently unreliable moisture supply away from the base of the gully, combined with likely susceptibility to fire. There is 
evidence of branch recovery after fire and recent fires have affected leaves on outer branches but not the main trunk or trunks (if coppiced).

\section{Phenology}

In 2010 and 2012, mass flowering occurred $~ 4$ weeks after a substantial rainfall event $(>200 \mathrm{~mm})$, preceded by an extended dry period of 7 months with rainfall less than $25 \mathrm{~mm}$ per month. In 2010 , three dry months were followed by 3 months of moderate rainfall (mean $60 \mathrm{~mm}$ per month), followed by 4 months with rainfall greater than $200 \mathrm{~mm}$ per month. In October 2010, flowers were observed and collected from one small branch. Despite regular observations by John Elliott and Keith Townsend, flowering was not observed until January 2012. Fruits were collected in February 2012, 3 weeks after flowering. In May 2010 , old fruits were present on some branches, although most were among rocks; it is assumed that these resulted from a flowering in January 2010.

\section{Etymology}

Named for the disseminule, which has four wings and is the distinctive characteristic of this species.

\section{Conservation status}

Rare - known only from only one population. All the trees are within the boundaries of the Townsville City Council Scenic Reserve and the Mount Stuart Army Training area and adjacent to an escarpment. A status of endangered is recommended, dependent on species response to myrtle rust.

\section{Notes}

In previous surveys of the Mount Stuart area near Townsville, $B$. tetraptera has almost certainly been misidentified as Gossia bidwillii. (Benth.) N.Snow \& Guymer. In May 2010, John Elliott noticed the unusual disseminules lodged among the rocks. Despite regular visits to the area between May 2010 and October 2011, no other disseminules were found. Flowers were collected from one branch of a small tree in October 2010; no disseminules were subsequently observed.

The distinguishing features of this species are associated with the 'perigynium'. This term was preferred by Briggs and Johnson (1979) to hypanthium. They defined it as a "cup or tube around the ovary (whether phylogenetically derived from receptacular tissue or from 'fusion' of the outer floral whorls) bearing the outer floral organs at or near its distal edge and sometimes extending upwards and outwards beyond the ovary'. This term has been chosen here because, in this species, the structure arises below the ovary and is not fused to the ovary, in fruit it encloses the ovary and is inflated with four obvious wings. A club-shaped nectary is almost completely hidden in each angle of the perigynium. The vascular trace to the nectary departs from the central cylinder before traces departing to the carpel bundles and the placentae. This nectariferous tissue appears to be non-functional. Fresh flowers stained with aqueous neutral red failed to show any activity, and no fragrance was noted after flowers were sealed in vials for $3 \mathrm{~h}$.
The flowers appear to be protandrous with the style longer in older flowers than at anthesis. Few abnormal pollen grains were observed when viewed at $400 \times$ magnification. Nearly all fruits examined were parasitised.

Backhousia leptopetala (F.Muell.) M.G.Harr., comb. nov.

Basionym: Syncarpia leptopetala F.Muell., Fragmenta Phytographiae Australiae 1(4): 79 (1859). Metrosideros leptopetala (F.Muell.) F.Muell., Systematic Census of Australian Plants 59 (1882). Nania leptopetala (F.Muell.) Kuntze, Revisio Generum Plantarum 1: 242 (1891) (as 'leptoclada'). Choricarpia leptopetala (F.Muell.) Domin, Bibliotheca Botanica Heft 89(4): 472, tafel 32, fig. 10-13 (1928).

Type: Queensland: in bush, Brisbane River, W. Hill (holo: MEL, n.v.).

Backhousia subargentea (C.T.White) M.G.Harr., comb. nov.

Basionym: Syncarpia subargentea C.T.White, Botany Bulletin. Department of Agriculture and Stock, Queensland 21: 8, t. 3 (1919). Choricarpia subargentea (C.T.White) L.A.S.Johnson, Contributions from the New South Wales National Herbarium 3(3): 100 (1961).

Type: Queensland: Imbil, F.H. Weatherhead (holo: BRI, n.v.)

Syncarpia subargentea var. latifolia C.T.White, Botany Bulletin. Department of Agriculture and Stock, Queensland 21: 8 (1919). Type: Imbil, F.H. Weatherhead (holo: BRI, n.v.).

\section{Acknowledgements}

For sampling assistance for the molecular dataset we acknowledge Dr Peter Wilson, Gary Sankowsky and Andrew Ford and, for laboratory support, Alessia Mortari. This work was, in part, funded by James Cook University (JCU) and CSIRO research funding to M. G. Harrington. This support is gratefully acknowledged. For assistance with $B$. gundarara, we thank the Botanic Gardens and Parks Authority, Dunkeld Pastoral, Paul Doughty and the Western Australian Museum, and William (Butch) Maher for providing helicopter time and field assistance that enabled M. D. Barrett and R. L. Barrett to collect the type specimen of B. gundarara. Thanks go to Garry and Nada Sankowsky, Wayne O'Sullivan and Dave Dureau for bringing $B$. gundarara to light and assisting to relocate fertile plants. The illustration of $B$. gundarara was produced by Nadine Guthrie (PERTH). Without the efforts of John Elliott, $B$. tetraptera would have remained unnoticed. Sincere thanks go to John Elliott and Keith Townsend who, in association with other members of the Townsville Branch of the Society for Growing Australian Plants, have visited the grove every few weeks. Sue Reilly (JCU histologist) prepared the sections of the flowers and wood for analysis. Bruce Bowden (JCU) made a preliminary analysis of the oil content of the leaves and Joe Brophy (UNSW) then confirmed these results by using a different technique. The Australian Defence Force has given the 'team' permission to regularly traverse their land. The illustration of $B$. tetraptera was produced by Ashley Field (CNS).

\section{References}

Bamber RK (1962) The anatomy of the barks of Leptospermoideae. Australian Journal of Botany 10, 25-54. doi:10.1071/BT9620025

Barlow BA, Hyland BP (1988) The origins of the flora of Australia's wet tropics. Proceedings of the Ecological Society of Australia 15, 1-17.

Barraclough TG, Vogler AP (2002) Recent diversification rates in North America tiger beetles estimated from a dated mtDNA phylogenetic tree. Molecular Biology and Evolution 19, 1706-1716. doi:10.1093/oxfordjournals.molbev.a003993 
Biffin E, Lucas EJ, Craven LA, Ribeiro da Costa I, Harrington MG, Crisp MD (2010) Evolution of exceptional species richness amongst lineages of fleshy fruited Myrtaceae. Annals of Botany 106, 79-93. doi:10.1093/aob/mcq088

Briggs BG, Johnson LAS (1979) Evolution in the Myrtaceae: evidence from inflorescence structure. Proceedings of the Linnean Society of New South Wales 102, 157-256.

Brophy JJ, Goldsack RJ, Forster PI (1994) The essential oils of Choricarpia leptopetala (F.Muell.) Domin and C. subargentea (C.T.White) L.A.S. Johnson (Myrtaceae). Flavour and Fragrance Journal 9, 7-10. doi:10.1002/ffj.2730090103

Brophy JJ, Goldsack RJ, Fookes CJ, Forster PI (1995) Leaf oils of the genus Backhousia (Myrtaceae). Journal of Essential Oil Research 7, 237-254. doi:10.1080/10412905.1995.9698514

Brophy JJ, Goldsack RJ, Craven LA, Ford AJ (2007) Leaf oil of Backhousia enata (Myrtaceae). Journal of Essential Oil Research 19, 26-27. doi:10.1080/10412905.2007.9699221

Brown JM, Lemmon AR (2007) The importance of data partitioning and the utility of Bayes factors in Bayesian phylogenetics. Systematic Biology 56, 643-655. doi:10.1080/10635150701546249

Carnegie A, Lidbetter JR (2012) Rapidly expanding host range for Puccinia psidii sensu lato in Australia. Australasian Plant Pathology 41, 13-29. doi:10.1007/s13313-011-0082-6

Crisp MD, Cook LG, Steane DA (2004) Radiation of the Australian flora: what can comparisons of molecular phylogenies across multiple taxa tell us about the evolution of diversity in present-day communities? Philosophical Transactions of the Royal Society B - Biological Sciences 359, 1551-1571. doi:10.1098/rstb.2004.1528

Drummond AJ, Rambaut A (2007) BEAST: Bayesian evolutionary analysis by sampling trees. BMC Evolutionary Biology 7, 214. doi:10.1186/1471-2148-7-214

Floyd AG (1989) 'Rainforest trees of Mainland South-eastern Australia.' (Inkata Press: Melbourne)

Ford AJ, Craven LA, Brophy JJ (2005) Backhousia enata A.J.Ford, Craven \& J.Holmes (Myrtaceae), a new species from north-eastern Queensland. Austrobaileya 7, 121-127.

Gadek PA, Martin HA (1981) Pollen morphology in the subtribe Metrosiderinae of the Leptospermoideae (Myrtaceae) and its taxonomic significance. Australian Journal of Botany 29, 159-184. doi:10.1071/BT9810159

Greenwood DR, Herold N, Huber M, Müller RD, Seton M (2012) Early to middle Miocene monsoon climate in Australia. Geology 40, e274. doi:10.1130/G33384Y.1

Guymer GP (1988) A new species of Backhousia Hook. \& Harvey (Myrtaceae) from Queensland and a reappraisal of Backhousia floribunda A.J.Scott. Austrobaileya 2, 567-569.

Herold N, Huber M, Greenwood DR, Müller RD, Seton M (2011) Early to middle Miocene monsoon climate in Australia. Geology 39, 3-6. doi: $10.1130 / \mathrm{G} 31208.1$

Ingle HD, Dadswell HE (1953) The anatomy of the timbers of the south-west Pacific area. III. Myrtaceae. Australian Journal of Botany 1, 353-401. doi:10.1071/BT9530353

Jackes BR (2005) Revision of Myrsine (Myrsinaceae) in Australia. Australian Systematic Botany 18, 399-438. doi:10.1071/SB04022

Kass RE, Rafferty AE (1995) Bayes factors. Journal of the American Statistical Association 90, 773-795. doi:10.1080/01621459.1995.10476572

Katoh K, Toh H (2008) Recent developments in the MAFFT multiple sequence alignment program. Briefings in Bioinformatics 9, 286-298. doi:10.1093/bib/bbn013

Kenneally KF, Keighery GJ, Hyland BM (1991) Floristics and phytogeography of Kimberley rainforests, Western Australia. In 'Kimberley Rainforests Australia. (Eds NL McKenzie, RB Johnston, PG Kendrick) pp. 93-131. (Surrey Beatty: Sydney)
Kershaw AP, Martin HA, McEwen Mason JR (1994) The Neogene: a period of transition. In 'History of the Australian Vegetation: Cretaceous to Recent'. (Ed. RS Hill) pp. 299-327. (Cambridge University Press: Cambridge, UK)

Kress WJ, Wurdack KJ, Zimmer EA, Weigt LA, Janzen DH (2005) Use of DNA barcodes to identify flowering plants. Proceedings of the National Academy of Sciences, USA 102, 8369-8374. doi:10.1073/pnas.0503123102

Ladiges PY, Udovicic F, Nelson G (2003) Australian biogeographical connections and the phylogeny of large genera in the plant family Myrtaceae. Journal of Biogeography 30, 989-998. doi:10.1046/j.1365-2699.2003.00881.x

Liddle DT, Russell-Smith J, Brock J, Leach GJ, Conners GT (1994) 'Atlas of the Vascular Rainforest Plants of the Northern Territory.' (Australian Biological Resources Study: Canberra)

Martin HA (2006) Cenozoic climate change and development of the arid vegetation in Australia. Journal of Arid Environments 66, 533-563. doi:10.1016/j.jaridenv.2006.01.009

Miller MA, Pfeiffer W, Schwartz T (2010) Creating the CIPRES Science Gateway for inference of large phylogenetic trees. In 'Proceedings of the Gateway Computing Environments Workshop (GCE)'. 14 November 2010, New Orleans, LA. pp. 1-8. (Cyberinfrastructure for Phylogenetic Research) Available at http://www.phylo.org/sub_sections/portal/ sc2010_paper.pdf [Verified 8 November 2012]

Mueller FJH (1859) 'Fragmenta Phytographiae Australiae.' 1(4). (Melbourne Printers: Melbourne)

Pybus OG, Harvey PH (2000) Testing macro-evolutionary models using incomplete molecular phylogenies. Proceedings of the Royal Society of London B - Biological Sciences 267, 2267-2272. doi: $10.1098 /$ rspb.2000.1278

Rambaut A, Drummond AJ (2007) 'Tracerv1.5.' Available at http://beast.bio. ed.ac.uk/Tracer [Verified 8 November 2012]

Ronquist F, Huelsenbeck JP (2003) MRBAYES 3: Bayesian phylogenetic inference under mixed models. Bioinformatics 19, 1572-1574. doi:10.1093/bioinformatics/btg180

Savolainen V, Anstett M-C, Lexer C, Hutton I, Clarkson JJ, Norup MV, Powell MP, Springate D, Salamin N, Baker WJ (2006) Sympatric speciation in palms on an oceanic island. Nature 441, 210-213. doi: 10.1038/nature 04566

Shaw J, Small RL (2004) Addressing the 'hardest puzzle in American pomology'. Phylogeny of Prunus sect. Prunocerasus (Rosaceae) based on seven noncoding chlopoplast DNA regions. American Journal of Botany 91, 985-996. doi:10.3732/ajb.91.6.985

Sniderman JR, Jordan GJ (2011) Extent and timing of floristic exchange between Australian and Asian rain forests. Journal of Biogeography 38, 1445-1455. doi:10.1111/j.1365-2699.2011.02519.x

Stamatakis A, Ludwig T, Meier H (2005) RAxML1-III: a fast program for maximum likelihood-based inference of large phylogenetic trees. Bioinformatics 21, 456-463. [Published online early 17 December 2004] doi:10.1093/bioinformatics/bti191

Sun Y, Skinner DZ, Liang GH, Hulbert SH (1994) Phylogenetic analysis of Sorghum and related taxa using internal transcribed spacers of nuclear ribosomal DNA. Theoretical and Applied Genetics 89, 26-32. doi:10.1007/BF00226978

Swofford DL (2002) 'PAUP*. Phylogenetic Analysis Using Parsimony (*and Other Methods). Sinauer Associates, Sunderland, MA)

Thornhill AH, Popple LW, Carter RJ, Ho SY, Crisp MD (2012a) Are pollen fossils useful for calibrating relaxed molecular clock dating of phylogenies? A comparative study using Myrtaceae. Molecular Phylogenetics and Evolution 63, 15-27. doi:10.1016/j.ympev.2011.12.003

Thornhill AH, Hope GS, Craven LA, Crisp MD (2012b) Pollen morphology of the Myrtaceae. Part 2: tribes Backhousieae, Melaleuceae, Metrosidereae, Osbornieae and Syzygieae. Australian Journal of Botany 60, 200-224. doi:10.1071/BT11175 
Travouillon KJ, Legendre S, Archer M, Hand SJ (2009) Palaeoecological analyses of Riversleigh's Oligo-Miocene sites: implications for Oligo-Miocene climate change in Australia. Palaeogeography, Palaeoclimatology, Palaeoecology 276, 24-37. doi:10.1016/j.palaeo.2009.02.025

Travouillon KJ, Archer M, Hand SJ (2012) Early to middle Miocene monsoon climate in Australia. Geology 40, e273. doi:10.1130/G32600C.1

White CT (1919) Contributions to the Queensland flora. Department of Agriculture and Stock, Queensland, Botany Bulletin 21. (Brisbane)

White TJ, Bruns T, Lee S, Taylor J (1990) Amplification and direct sequencing of fungal ribosomal RNA genes for phylogenetics. In 'PCR Protocols: a Guide to Methods and Applications'. (Eds MD Innis, D Gelfand, J Sninsky, T White) pp. 315-322. (Academic Press: San Diego, CA)
Wilson PG (2011) Myrtaceae. In 'The families and genera of vascular plants. X. Flowering Plants. Eudicots: Sapindales, Cucurbitales, Myrtaceae'. (Ed. K Kubitzki) pp. 212-271. (Springer-Verlag: Berlin)

Wilson PG, O'Brien MM, Quinn CJ (2000) Anetholea (Myrtaceae) a new genus for Backhousia anisata: a cryptic member of the Acmena alliance. Australian Systematic Botany 13, 429-435. doi:10.1071/SB99008

Wilson PG, O'Brien MM, Heslewood MM, Quinn CJ (2005) Relationships within Myrtaceae sensu lato based on a matK phylogeny. Plant Systematics and Evolution 251, 3-19. doi:10.1007/s00606-004-0162-y

Zhou LL, Su YCF, Thomas DC, Saunders RM (2012) 'Out-of-Africa' dispersal of tropical floras during the Miocene climatic optimum: evidence from Uvaria (Annonaceae). Journal of Biogeography 39, 322-335. doi:10.1111/j.1365-2699.2011.02598.x 
Appendix 1. Vouchers and GenBank accession numbers for taxa used in phylogenetic analyses

\begin{tabular}{|c|c|c|c|c|c|c|c|}
\hline Species & $\begin{array}{l}\text { Voucher (for } \\
\text { new accessions) }\end{array}$ & $\operatorname{mat} \mathrm{K}$ & rps 16 & $\operatorname{trn} \mathrm{H}-p s b \mathrm{~A}$ & $\operatorname{trn} \mathrm{C}-p s b \mathrm{M}$ & $\operatorname{trn} \mathrm{L}-\mathrm{F}$ & ITS \\
\hline \multicolumn{8}{|l|}{ Backhousieae } \\
\hline $\begin{array}{l}\text { Backhousia angustifolia } \\
\text { F.Muell. }\end{array}$ & $\begin{array}{l}\text { B Hyland } 25921 \\
\text { RFK (CNS) }\end{array}$ & & & KC134149 & KC134183 & $\mathrm{KC} 134170$ & KC134136 \\
\hline $\begin{array}{l}\text { Backhousia bancroftii } \\
\text { F.M.Bailey }\end{array}$ & $\begin{array}{l}\text { Costion } 1800 \\
\quad(\mathrm{CNS})\end{array}$ & $\mathrm{KC} 134162$ & $\mathrm{KC} 134127$ & $\mathrm{KC} 134150$ & $\mathrm{KC} 134184$ & KC134171 & KC134137 \\
\hline $\begin{array}{l}\text { Backhousia citriodora } \\
\text { F.Muell. }\end{array}$ & RBG 14090 & AY525129 & $\mathrm{KC} 134128$ & $\mathrm{KC} 134151$ & $\mathrm{KC} 134185$ & $\mathrm{KC} 134172$. & KC134138 \\
\hline Backhousia enata A.J.Ford & $\begin{array}{l}\text { Craven \& J. } \\
\text { Holmes, A Ford } \\
3780(\mathrm{CNS})\end{array}$ & $\mathrm{KC} 134163$ & & $\mathrm{KC} 134152$ & $\mathrm{KC} 134186$ & KC134173 & KC134139 \\
\hline $\begin{array}{l}\text { Backhousia hughesii } \\
\text { C.T.White }\end{array}$ & $\begin{array}{l}\text { A Ford } 3977 \\
\text { (CNS) }\end{array}$ & $\mathrm{KC} 134164$ & KC134129 & $\mathrm{KC} 134153$ & KC134187 & $\mathrm{KC} 134174$ & KC134140 \\
\hline Backhousia kingii Guymer & $\begin{array}{l}\text { PI Forster } 14489 \\
\text { (CNS) }\end{array}$ & & & $\mathrm{KC} 134155$ & KC134189 & $\mathrm{KC} 134176$ & $\mathrm{KC} 134142$ \\
\hline $\begin{array}{l}\text { Backhousia myrtifolia } \\
\text { Hook. \& Harv. }\end{array}$ & RBG $14095^{\mathrm{A}}$ & AF368200 & $\mathrm{KC} 134131$ & KC134156 & KC134190 & KC134177 & $\mathrm{KC} 134143$ \\
\hline $\begin{array}{l}\text { Backhousia oligantha } \\
\text { A.R.Bean }\end{array}$ & $\begin{array}{l}\text { PI Forster } 7525 \\
\text { (CNS) }\end{array}$ & & & $\mathrm{KC} 134157$ & KC134191 & $\mathrm{KC} 134178$ & KC134144 \\
\hline $\begin{array}{l}\text { Backhousia sciadophora } \\
\text { F.Muell. }\end{array}$ & $\begin{array}{l}\text { PI Forster } 6203 \\
\text { (CNS) }\end{array}$ & KC134166 & $\mathrm{KC} 134132$ & $\mathrm{KC} 134158$ & $\mathrm{KC} 134192$ & $\mathrm{KC} 134179$ & KC134145 \\
\hline $\begin{array}{l}\text { Backhousia sp. Prince } \\
\text { Regent (W.O’Sullivan \& } \\
\text { D.Dureau WODD 42) } \\
\text { WA Herbarium }\end{array}$ & $\begin{array}{l}\text { G Sankowski } 2255 \\
\text { (PERTH) }\end{array}$ & $\mathrm{KC} 134165$ & $\mathrm{KC} 134130$ & $\mathrm{KC} 134154$ & $\mathrm{KC} 134188$ & $\mathrm{KC} 134175$ & KC134141 \\
\hline Backhousia sp. Mount Stuart & J.Elliott1 & KC134169 & KC134135 & KC134161 & KC134195 & KC134182 & KC134148 \\
\hline $\begin{array}{l}\text { Choricarpia leptopetala } \\
\text { (F.Muell.) Domin }\end{array}$ & RBG $14168^{\mathrm{A}}$ & KC134167 & KC134133 & KC134159 & KC134193 & KC134180 & KC134147 \\
\hline $\begin{array}{l}\text { Choricarpia subargentea } \\
\text { (C.T.White) L.A.S.Johnson }\end{array}$ & $\begin{array}{l}\text { BJ Wallace } 83024 \\
\text { (RBG) }\end{array}$ & KC134168 & $\mathrm{KC} 134134$ & KC134160 & KC134194 & KC134181 & KC134146 \\
\hline \multicolumn{8}{|l|}{ Kanieae } \\
\hline $\begin{array}{l}\text { Sphaerantia chartacea } \\
\text { Peter G.Wilson \& B.Hyland }\end{array}$ & AY521547 & & & & HM160115-6 & & HM160115-6 \\
\hline $\begin{array}{l}\text { Tristaniopsis laurina }(\mathrm{Sm} .) \\
\text { Peter G.Wilson \& J.T.Waterh. }\end{array}$ & AF184710 & & & & EF041514 & & EF041514 \\
\hline \multicolumn{8}{|l|}{ Metrosidereae } \\
\hline $\begin{array}{l}\text { Metrosideros diffusa } \\
\text { (G.Forst.) Sm. }\end{array}$ & AY521542 & & AM489848 & & & AF211500 & AF211500 \\
\hline $\begin{array}{l}\text { Metrosideros nervulosa } \\
\text { C.Moore \& F.Muell. }\end{array}$ & DQ088535 & JF950871 & AM489848 & & JF950926 & JF950781 & JF950783 \\
\hline \multicolumn{8}{|l|}{ Syzygieae } \\
\hline $\begin{array}{l}\text { Syzygium anisatum } \\
\text { (Vickery) Craven } \\
\text { \& Biffin }\end{array}$ & AF368195 & & AM489812 & & & DQ088407 & AY187225 \\
\hline Syzygium cumini (L.) Skeels & GQ870669 & GQ870669 & GQ870669 & GQ870669 & GQ870669 & JF682812 & JF682812 \\
\hline $\begin{array}{l}\text { Syzygium jambos (L.) } \\
\text { Alston }\end{array}$ & DQ088583 & & HQ415491 & & & JF682816 & JF682816 \\
\hline $\begin{array}{l}\text { Syzygium maire (A.Cunn.) } \\
\text { Sykes \& P.J.Garnock-Jones }\end{array}$ & DQ088589 & & & AM489883 & & EF026632 & EF026632 \\
\hline Syzygium smithii (Poir.) Nied. & AY525127 & & & & & AY187168 & AY187168 \\
\hline $\begin{array}{l}\text { Syzygium unipunctatum } \\
\text { (B.Hyland) Craven \& Biffin }\end{array}$ & DQ088623 & & & & & AY187224 & AY187224 \\
\hline \multicolumn{8}{|l|}{ Tristanieae } \\
\hline $\begin{array}{l}\text { Thaleropia queenslandica } \\
\text { (L.S.Sm.) Peter G.Wilson }\end{array}$ & AF368223 & & & & & AY264945 & AY264945 \\
\hline Xanthomyrtus & AF368226 & & AM489887 & & & AM234148 & AM234148 \\
\hline
\end{tabular}

${ }^{\mathrm{A}} \mathrm{RBG}$ indicate living collection numbers. 